DIGITALCOMMONS

—@WAYNESTATE-
Michigan Journal of Counseling:

Research, Theory and Practice

9-1-2011

\title{
Supporting and Preparing Future First-Generation College Students in the High School Environment: Implications for School Counselors
}

Jill K. Bryant

Indiana University South Bend, jill.bryant@wku.edu

Joanna Nicolas

Indiana University South Bend, mdjmnicolas@gmail.com

Follow this and additional works at: https://digitalcommons.wayne.edu/mijoc

\section{Recommended Citation}

Bryant, J. K., \& Nicolas, J. (2011). Supporting and Preparing Future First-Generation College Students in the High School

Environment: Implications for School Counselors, Michigan Journal of Counseling, 38(2), 17-26. doi:10.22237/mijoc/1314835320

This Article is brought to you for free and open access by the Open Access Journals at DigitalCommons@WayneState. It has been accepted for inclusion in Michigan Journal of Counseling: Research, Theory and Practice by an authorized editor of DigitalCommons@WayneState. 
Supporting and Preparing Future First-Generation College Students in the High School Environment: Implications for School Counselors

Jill K. Bryant

Indiana University South Bend

Joanna Nicolas

Indiana University South Bend

Abstract

This study surveyed college freshmen from two different institutions in order to examine differences between First-Generation College Students and Continuing-Generation College Students. Differences between groups emerged for high school academic preparation, college exploration behaviors, college application behaviors, and college decision-making prior to matriculation. Results suggest differences between groups are relevant to professional school counseling. Suggestions for interventions, school counseling implications, and future research are discussed.

According to the American School Counselor Association (ASCA) position statement on academic and career planning (2006), "professional school counselors implement academic and career planning based on students' abilities, interests, and goals with the hope of reducing inequities based on stereotypes or special needs, and is an important step towards equal access to postsecondary opportunities" (p. 1). The ASCA National Model (2005) designated individual student planning as a component of the delivery system providing "all students an opportunity to work closely with their parents or guardian to plan, monitor, and understand their growth and development and take action on their next steps personally, educationally, and occupationally" (p.15). Professional school counselors are charged with helping all students, but information is lacking in the specific needs of students who are the first in their family to pursue higher education. This study examined distinctions between FirstGeneration College Students (FGCS) and Continuing-Generation College Students (CGCS) with respect to academic preparation, college exploration, and the college decision-making process in an effort to assist professional school counselors in establishing data driven interventions to academically prepare and support FGCS as they prepare for post-secondary education..

Jill K. Bryant, Ph.D., NCC, LMHC, ACS is currently an assistant professor of counseling at Western Kentucky University. She was formerly an Assistant Professor of Counseling at Indiana University South Bend and may be reached at jill.bryant@wku.edu. Joanna Nicolas received her Masters of Education from Indiana University South Bend and currently works as a grief counselor specializing in grief work with children. She may be reached at mdjmnicolas@gmail.com. 


\section{First-Generation College Students}

First-generation college students are qualitatively different with regard to their demographic and background variables compared with CGCS. Recent studies posited slightly more than a quarter of high school graduates across the country are FGCS (Owens, Lacey, Rawls \& Hobert-Quince, 2010) and close to half of these FGCS came from a lower socioeconomic background (Choy, 2001). More recent studies also supported the likelihood that FGCS come from lower income families (Bui, 2002; Choy, 2001), disproportionately represent ethnic and minority groups (Engle \& Tinto, 2008), and are more likely to speak a language other than English in the home (Bui, 2002). In addition, FGCS are more likely to be older, married, and have dependents when compared to CGCS (Choy, 2001; Grimes \& Mehta, 2006).

Significant differences in academic preparation of FGCS were noted in previous studies and some differences corresponded with persistence once in the college setting. First-generation college students typically have lower grade point averages (GPAs) and lower SAT scores (Prospero \& Vohra-Gupta, 2007), and are less likely to take college entrance exams (Warburton, Burgarin, \& Nunez, 2001). Past research suggested FGCS were less likely to take advantage of honors programs (Pascarella, Pierson, Wolniak, \& Terenzini, 2004) or participate in college preparation courses (Horn \& Nunez, 2000). In a longitudinal study following a sample of students with above average skills in math and reading (both FGCS and CGCS), Trusty and Niles (2004) found coursetaking in high school to have the strongest effect in completion of a four-year degree. Choy (2000) reported the highest level of mathematics taken by FGCS in high school (beginning with algebra in eighth grade) exerted the strongest influence in completion of a bachelor's degree. It is also noteworthy that while a lack of academic preparation is not necessarily a barrier to entry for FGCS pursuing post-secondary education, it does correlate with success once enrolled in the college setting (Ishanti, 2003).

When it comes to college selection, FGCS demonstrate differences in choice and decisional influences compared with students who have a parent with previous post-secondary experience (Bui, 2002). Due to their own lack of experience, parents of FGCS may be less able or willing to help their student with the planning, application, and decision-making process (Gibbons \& Shoffner, 2004). According to Pascarella et al. (2004), "compared to their peers with highly educated parents, first-generation students are more likely to be handicapped in accessing and understanding information and attitudes relevant to making beneficial decisions" (p. 252). Horn and Nunez (2000) discerned that the probability of enrolling in college increased for FGCS when their parents participated in college preparation activities, and when these students received additional support from their high school in navigating the college application process.

Past research focused on specific demographic variables for FGCS as well as academic preparation, cognitive abilities, retention, and transitioning. Curiously, previous studies neglected to explore specific readiness and decisional factors from the school counseling perspective, although professional school counselors are ideally situated to assist these students in a preventative 
fashion prior to graduation. This inquiry surveyed freshmen from two distinct institutions in order to distinguish the disparity in college preparation behaviors between FGCS and CGCS. Results have implications for school counseling interventions expressly created to close the gap, and advocate for FGCS through their college preparation journey.

\section{Participants}

\section{Method}

The questionnaire was sent to 1,666 freshmen attending an urban university and 540 freshmen enrolled at a competitive private university for a total of 2,206 possible participants. Survey respondents were 366 college freshmen from these two Midwest institutions for a response rate of $17 \%$. Two hundred and seventy-seven of the respondents were from an urban university with the remaining 89 coming from the private university.

Eighteen questionnaires were incomplete and removed from the study. An additional participant endorsed "unknown" when asked about parental postsecondary educational experience and was also removed. Finally, because the sample contained a wide range of ages (from 17 to 67 years), the researchers decided to eliminate outliers from the study, removing all participants who reported their age as 29 or older. Consequently, 41 additional participants were removed leaving 306 participants in the study.

The sample was comprised of 200 women (65.4\%), and 106 men $(34.6 \%)$ ranging in age from 17 to 28 years $(M=20.11, S D=3.42)$. Seventyfive percent $(n=229)$ reported as White, non-Hispanic with remaining respondents reporting ethnicity as African-American (7.9\%), Hispanic/Latino (5.3\%), Asian/Pacific Islander (2.3\%), Native American (0.7\%), other (8.6\%) with one failing to respond to this item. Integral to this study was the post-secondary educational background of the parents of the sample. The majority of respondents reported having one or both parents graduating from college or attending college but not graduating $(72.5 \%, n=222)$ with the remainder of the sample stating his or her parents had no college education $(27.5 \%, n=84)$.

\section{Research Materials}

The authors developed a questionnaire exclusively for this study, with additional feedback from professors who had an expertise in working with freshmen populations. Item creation was embedded in previous research on FGCS with additional focus on college decisional influences, high school preparation behaviors, college exploration behaviors, and social and familial pressures and support. The questionnaire was distributed to several faculty members and graduate students for feedback and suggested revisions.

The questionnaire consisted of six sections. Section one, Participant Information, contained demographic questions while the second section, Family Information, included questions on family background. Section three, High School Information, was comprised of questions exploring basic academic information (i.e., GPA and class ranking) in addition to academic rigor offered and taken during high school. The fourth section, College Exploration and Application, contained questions on exploration behaviors (i.e., college visits, college fairs), and the college application process, while section five, College Decision- 
Making, included questions on priority variables, decision-making pressures, and decisional influences. The final section, Support Systems, examined peer and family support for attending college, utilization of college support structures, and perceived pressures in the college transitional process.

Subsets of the questionnaire evidenced moderate to strong reliability. Internal consistency measures using Chronbach's alpha ranged from .61 to .70 for the subsets measuring academic rigor offered and academic rigor taken. Reliability measures for college exploration, peer influence, and college decision-making ranged from .66 to .73 with several stand-alone items also reported in this analysis.

\section{Procedure}

Upon final approval from the home Institutional Review Board of the researchers, in addition to the Institutional Review Boards for each of the sites, an email list of all freshmen was obtained from each institution. Participants were sent an invitation email orienting them to the study, the forthcoming survey invitation, and informed consent. Three days later participants received an invitation email including a link to the online survey with informed consent embedded in the survey document. Participants received follow-up email reminders at one and two weeks after the original invitation. The cover letter clarified participation in the study was voluntary and consent was indicated by completion of the online survey. Participants were notified that all information would be used in aggregate form, and while no identifying information would be gathered, transmission of responses over the Internet is not completely confidential. No incentives were offered for participation in this study.

\section{Demographics}

\section{Results}

As stated earlier, a number of age outliers were removed prior to analysis. An Analysis of Variance was performed for age differences between the two groups (i.e., FGCS and CGCS) as noted in previous studies. The analysis was significant $(F(1,276)=11.186, p=.001)$. With a range of $17-28$ years, FGCS were still over a year older $(M=21.13, S D=4.08)$ than their CGCS counterparts $(M=19.71, S D=2.76)$. Likewise, an ANOVA examining differences in the years reported since graduation from high school yielded significance $(F(1$, $293)=7.201, p=.008$ ) with FGCS reporting more time from graduation to freshman status $(M=2.75$ years, $S D=2.97)$ than CGCS $(M=1.91$ years, $S D=$ 2.11). No significant differences were found for this sample when it came to ethnicity, SES, marital status, or family of origin structure (e.g., dual or singleparent) which is significant because these findings are inconsistent with past studies.

\section{High School Experience}

When high school GPA and high school class rank were compared, significant differences were minimal. Likewise, no differences emerged for time spent doing homework while in high school. While no significance emerged when asked if their school offered honors courses, differences were found in the 
number of honors classes taken. Continuing-generation college students took significantly more honors courses $x^{2}(3, N=291)=12.82, p=.005$, effect size .210. Specifically, $27.6 \%$ of CGCS took six or more $(16.9 \%$ of them 10 or more) compared with FGCS (12.8\% taking six or more) while on the other end of the continuum $74.3 \%$ of FGCS reported taking $0-2$ honors courses compared with $53.5 \%$ of CGCS.

To further examine academic rigor in high school, participants responded to several items regarding advanced placement (AP) courses offered and taken. The majority of both groups reported their high school offered AP courses $(88.8 \%$ of the FGCS sample and $93.8 \%$ of the CGCS sample). However, when reporting the number of AP courses taken, group differences were found $X^{2}(1, N=300)=13.31, p<.000$, effect size .211 with only $22.8 \%$ of FGCS taking any AP courses compared with $46.3 \%$ of their CGCS counterparts. Therefore, while both groups attended schools where academic rigor was offered, FGCS did not pursue more demanding coursework or were not encouraged or allowed (i.e., didn't meet prerequisites) to do so.

Table 1-High School Experience

\begin{tabular}{|l|c|c|c|c|c|}
\hline & FGCS & CGCS & $X^{2}$ & $p$ & $\Phi$ \\
\hline High School GPA 3.5 or Above & $44.5 \%$ & $44.8 \%$ & 8.431 & .077 & .167 \\
\hline High School Rank Top 10\% & $20.9 \%$ & $30.0 \%$ & 4.240 & .752 & .119 \\
\hline $\begin{array}{l}\text { Honors Courses Offered High } \\
\text { School }\end{array}$ & $84.1 \%$ & $93.7 \%$ & 9.022 & .011 & .173 \\
\hline $\begin{array}{l}15 \text { Hours or More Hours of } \\
\text { Homework Per Week }\end{array}$ & $3.7 \%$ & $9.5 \%$ & 3.944 & .227 & .114 \\
\hline Honors Courses Taken & $12.8 \%$ & $27.6 \%$ & 12.82 & .005 & .210 \\
\hline High School Offered AP & $88.8 \%$ & $93.8 \%$ & & & .000 \\
\hline AP Courses Taken & $22.8 \%$ & $46.3 \%$ & 13.31 & .211 \\
\hline
\end{tabular}

\section{College Exploration, Application}

Groups differed when it came to college fair attendance $X^{2}(1, N=294)$ $=4.90, p=.027$, effect size .129 with $47.1 \%$ of CGCS reporting they had gone to one or more college fairs compared with $32.9 \%$ of FGCS. An AVOVA revealed significance for college visits (range 1 to 20 ), with CGCS reporting more college visits $(M=3.70$ visits, $S D=3.10)$ than FGCS $(F(1,204)=12.453, p$ $<.001)$. Even though differences were present, when responding whether they wished they could have gone on more college visits, no differences emerged $x^{2}$ $(1, N=330)=1.18, p=.277$. Finally, in order to explore barriers to this college exploration activity, participants were asked to respond to a list of possible reasons for attending fewer college visits. Reasons given are found in Table 2. 


\begin{tabular}{|l|l|l|}
\hline & FGCS & CGCS \\
\hline Couldn't Miss That Much School & $50.0 \%$ & $47.0 \%$ \\
\hline Couldn't Afford It & $34.7 \%$ & $55.0 \%$ \\
\hline Too Far Away & $41.3 \%$ & $32.0 \%$ \\
\hline No Way to Get There & $28.3 \%$ & $37.0 \%$ \\
\hline No One to Take Me & $28.3 \%$ & $43.0 \%$ \\
\hline Other & $43.5 \%$ & $40.0 \%$ \\
\hline
\end{tabular}

Responses to the number of college applications submitted yielded significant differences as well, with CGCS submitting more applications than FGCS $(F(1,284)=10.075, p<.002)$. Participants also responded to a question asking if they had had assistance in preparing college applications and differences were present $x^{2}(1, N=292)=6.66, p=.010$, effect size .151 . In this sample, CGCS $(63.5 \%)$ were much more likely to have received or requested help on college applications than the FGCS sample (46.9\%) even though research is clear that it is FGCS who are at a disadvantage in this area.

\section{College Decision-Making}

Chi-square analysis found differences between groups $X^{2}(1, N=291)=$ $6.38, p=.008$, effect size .154 with FGCS much more likely to consider not enrolling in college (46.9\%) than CGCS (30.4\%). Participants reported the number of friends considering attending college from a list of five choices ranging from nearly all to none. Chi-square analysis found significance $x^{2}(4, N=290)=$ 23.18, $p<.000$, effect size .283 with CGCS reporting most to nearly all of their friends attending college (94.7\%) compared with FGCS (63.0\%). Items exploring peer involvement in the decision-making process, found CGCS much more likely to discuss their college decision-making with peers than FGCS $x^{2}(1, N=$ $277)=8.578, p<.003$, effect size .176 while FGCS felt far more peer pressure to not attend college than was reported by $\operatorname{CGCS~X}^{2}(1, N=277)=11.65, p$ $<.001$, effect size .205 .

Table 3-College Decision-Making

\begin{tabular}{|l|c|c|c|c|c|}
\hline & FGCS & CGCS & $\chi^{2}$ & $p$ & $\Phi$ \\
\hline Considered Not Going to College & $46.9 \%$ & $30.4 \%$ & 6.38 & .008 & .154 \\
\hline $\begin{array}{l}\text { Friends Considering Attending } \\
\text { College }\end{array}$ & $63.0 \%$ & $94.7 \%$ & 23.18 & .000 & .238 \\
\hline $\begin{array}{l}\text { Discussed College Decision- } \\
\text { Making with Peers }\end{array}$ & $67.9 \%$ & $84.4 \%$ & 8.58 & .003 & .176 \\
\hline $\begin{array}{l}\text { Felt Pressure Not to Attend } \\
\text { College }\end{array}$ & $48.8 \%$ & $30.8 \%$ & 11.65 & .001 & .205 \\
\hline
\end{tabular}




\section{Discussion}

Age-differences between FGCS and CGCS have been a consistent finding in previous studies (Choy, 2001; Grimes \& Mehta, 2006). This study found FGCS are still older, but only by a little over a year. One explanation may suggest FGCS are less likely, initially, to consider post-secondary studies, but over time are willing to enroll in a college or university. Another possibility is that FGCS have an inadequate college preparation and search period during high school, and don't have the plans in place to launch directly after graduation. Future research should examine both the reasons for dismissing college as an option and the motivations and decision-making variables that lead FGCS eventually to pursue higher education.

Past studies have found differences in the level of academic rigor between FGCS and CGCS (Choy, 2000; Horn \& Bobbit, 2000; Horn \& Nunez, 2000; Trusty \& Niles, 2004; Warburton et al., 2001). Contrary to previous research (Prospero \& Vohra-Gupta, 2007), this study found no differences in reported GPA or class rank for the two groups. This discovery suggests this gap between FGCS and CGCS may be diminishing. In this sample, CGCS reported taking more honors and AP courses than FGCS. While these results are similar to previous research, this study controlled for academic rigor offered in the high school setting, and found between group differences still present. Perhaps FGCS lack relevant information regarding the academic expectations to prepare for college, or results may reflect ambivalence towards pursuing higher education

Part of the college preparation journey includes researching, applying to, as well as visiting possible post-secondary choices. In this sample, CGCS attended more college fairs held within their school, went on significantly more college visits, and requested help on their applications more often than FGCS. These results support the assertion of Gibbons and Shoffner (2004) that FGCS may be at a disadvantage in their own college preparation activities because their parents lack the experience and perhaps the self-efficacy not only to help them with their preparation, but also to advocate for support when they are unable to provide it. Results also support the proposition of Horn and Nunez (2000) that FGCS would benefit from programs in secondary schools aimed at involving parents in the college exploration, preparation, and application process.

To better examine the post-secondary decision-making process, participants responded to several questions exploring college choice. First, we looked at the most basic choice (i.e., whether or not to go to college) and for this sample FGCS were more likely to admit they considered not attending college.

While this may not be surprising, it does suggest that we have yet to understand the social, familial, or personal influences for FGCS contributing to an early foreclosure decision with regard to their college. Our exploration of peer influence found CGCS discussed college plans with friends more often and not surprisingly had more friends with plans to pursue higher education. Conversely, FGCS reported they felt far more pressure not to attend college, raising the question of social influence and support for FGCS who are considering attending college after graduation. Such results suggest possible ambivalence for FGCS and may explain why students who are not sure they can go or are not sure they want to go to college would not pursue the academic rigor and college preparation be- 
haviors found in students who had always planned on attending college after graduation. Findings support the notion that earlier intervention in college counseling will afford students the ability to create realistic plans for their future that may influence their academic and college preparation choices.

\section{Implications for Professional School Counselors}

According to ASCA (2009), "professional school counselors promote equity and access to rigorous educational experiences for all students" (p. 1). The Education Trust, in the New Vision for School Counseling (2009), advocates that school counselors "foster educational equity, access, and academic success in a rigorous curriculum to ensure that all students graduate from high school ready to succeed in college and careers" (p. 1). School counselors may wish to specifically identify FGCS and implement a monitoring program exclusively for this population. Psychoeducational programs at the large or small group level would also be appropriate for service delivery.

Parents are integral to the college preparation journey, and parents who did not attend college, or who come from a family with few college graduates are at a disadvantage in assisting and supporting their student. School counselors should begin in middle school identifying and meeting with these parents. Furthermore, school counselors should address not only basic college information (e.g., college entrance exams, financial aid, college applications), but also the familial variables noted in the literature. If students are ambivalent about attending college, school counselors could explore possible parental influences for this ambivalence. Professional school counselors may find it most appropriate to address these concerns in group settings with parents as a group format offers additional therapeutic factors which may increase the efficacy of the intervention.

Ultimately, FGCS need extra attention and assistance when it comes to college exploration. Professional school counselors, as part of their monitoring process and/or individual planning, could include attendance at college fairs or meetings with visiting college admission representatives as a component of the plan. Mentoring FGCS on the college application process is vital, and creation of a program to do so would assist in closing this gap in opportunity between groups. These students may also need help in planning and pursuing more college visits. Since FGCS in this study attended few college visits prior to their freshman year, and since research also suggests that these students struggle with the cultural transition to college life, taking advantage of additional college visits may help.

\section{Limitations}

Several limitations to this study are worth noting. First, both institutions were located in the Midwest. Therefore, it is possible that this sample may not be representative although institutions were dissimilar in a number of factors improving generalizability. The questionnaire used for this study was a selfdeveloped inventory, and as such may contain some fundamental bias in construction, and a lack of reliability and validity data. The data for this study were self-reported, and consequently responses may have been influenced by social desirability. Likewise, questions asked participants to recall their high school 
experience, and there may have been error in participants' recollections. The low response rate also may suggest some possible nonresponse bias. With regard to the data analysis, some respondents were removed due to age (i.e., outliers) so while this decision may be helpful for the purpose of the research questions, the participants removed did indeed represent the current freshmen population in our country at the present time. In addition, the majority of participants in this study were White, even though the largest institution sampled for this study came from an ethnically, racially, and religiously diverse student population. This fact may also limit generalizability.

\section{Conclusion}

With a recent national focus on increasing college graduation rates in addition to the current economic challenges, a college education is more essential than ever before. In past decades, research has focused on the unique differences of FGCS, and their specific challenges in pursuing higher education. Predicated on the vision of the ASCA National Model (2005) and The Educational Trusts' New Vision for School Counseling (2009), professional school counselors are exceptionally qualified and uniquely positioned to address the distinct needs of FGCS. The needs identified in this study merge seamlessly with the vision, the delivery systems, and the themes articulated in the ASCA Model. The implications from this study suggest measurable outcomes emerging from some of the interventions specifically proposed (e.g., tracking higher level courses taken, GPAs, college visits, college exploration activities, career counseling, collaboration with parents, graduation rates, college admission rates, and retention rates in both high school and college). The journey towards higher education for FGCS can successfully advance with support from professional school counselors.

\section{References}

American School Counselor Association (2005). The ASCA national model: A framework for school counseling programs $\left(2^{\text {nd }}\right.$ ed. $)$. Alexandria, VA: Author.

American School Counselor Association (2006). The professional school counselor and academic and career planning http://asca2. timberlakepublishing.com//files/ PS_Academic\%20and\%20Career\%20Planning.pdf

American School Counselor Association (2009). The role of the professional school counselor. Retrieved from http://www.schoolcounselor.org/ content. asp? $\mathrm{pl}=325 \& \mathrm{sl}=133 \&$ contentid $=240$

Bui, K.V.T., (2002). First-generation college students at a four-year university: Background characteristics, reasons for pursuing higher education, and first-year experiences. College Student Journal, 36, 3-11.

Choy, S. (2001). Students whose parents did not go to college: Postsecondary access, persistence, and attainment. Washington, DC: National Center for Education Statistics. 
Engle, J., \& Tinto, V. (2008). Moving beyond access: College success for lowincome first generation college students. Retrieved from http:// www.coenet.us/files/files-Moving_Beyond_Access_2008.pdf

Gibbons, M.M., \& Shoffner, M.F. (2004). Prospective first-generation college students: Meeting their needs through Social Cognitive Career Theory. Professional School Counseling, 8 (1), 91-97.

Grimes, T., \& Mehta, S. (2006). Insight. St. Paul, MN: Minnesota Office of Higher Education.

Horn, L., \& Bobbit, L. (2000). Mapping the road to college: First-generation students' math track, planning strategies, and context of support. Washington, DC: U. S. Department of Education.

Horn, L., \& Nunez, A. (2000). Mapping the road to college: First-generation students' math track, planning strategies, and context of support. Washington, DC: National Center for Education Statistics.

Ishitani, T.T. (2003). A longitudinal approach to assessing attrition behaviors among first- generation students: Time varying effects of pre-college characteristics. Research in Higher Education, 44, 433-449. doi:10.1023/ A:1024284932709

Owens, D., Lacey, K., Rawls, G., \& Holbert-Quince, J. (2010). First-generation African-American male college students: Implications for career counselors. Career Development Quarterly, 58(4), 291-300.

Pascarella, E., Pierson, C.T., Wolniak, G.C., \& Terenzini, P.T. (2004). Firstgeneration college students: Additional evidence on college experiences and outcomes. Journal of Higher Education, 75(3), 249- 284. doi:10.1353/jhe.2004.0016

Prospero, M., \& Vohra-Gupta, S. (2007). First-generation college students: Motivation, integration, and academic achievement. Community College Journal of Research and Practice, 31, 963-975.

doi:10.1080/10668920600902051

The Education Trust (2009). The new vision for school counseling. Retrieved from http://www.edtrust.org/dc/tsc/vision

Trusty, J., \& Niles, S.G. (2004). Realized potential or lost talent: High school variables and bachelor's degree completion. The Career Development Quarterly, 53, 2-15.

Warburton, E.C., Bugarin, R., \& Nunez, A. (2001). Bridging the gap: Academic preparation and postsecondary success of first-generation students. Washington, DC: National Center for Education Statistics. 